\title{
Efficiency of regional mechanisms of state support of innovative activity: the case of Volgograd region
}

\author{
Sergei Sazonov \\ Volgograd State Technical University \\ Faculty of Economics and Management \\ Volgograd, Russia \\ art.97smol@yandex.ru
}

\author{
Mikhail Kovazhenkov \\ Volgograd State Technical University \\ Faculty of Economics and Management \\ Volgograd, Russia \\ art.97smol@yandex.ru
}

\author{
Artur Smolyanskii \\ Volgograd State Technical University \\ Faculty of Economics and Management \\ Volgograd, Russia \\ art.97smol@yandex.ru
}

\begin{abstract}
The article deals with the obstacles to the systemic transition of the Volgograd region to an innovative development path. The main of them are the underdevelopment of the regional innovation infrastructure and the unavailability of the Volgograd universities as primary recipients of state support within the framework of the subprogram "Development of innovative activity" to active innovative activity outside the educational process.
\end{abstract}

Keywords - innovation, innovation infrastructure, state support of innovations, commercialization of innovations

\section{INTRODUCTION}

The implementation of an innovative-oriented model of Russia's development in modern conditions is one of the strategic elements of modernizing the country's economy. Such a model requires not only an increase in production capacity based on the introduction of innovations and the gradual abandonment of an export-oriented economy, but also makes it necessary to seek new methods for managing innovations that focus on the potential of Russian regions and their place in the system of global and regional competitive markets for goods and services.

Given that in the last decade the role of the state in regulating Russian economic processes is constantly growing, state institutions are beginning to play a special role in stimulating the innovative activity of enterprises and organizations. This statement is true both for federal executive authorities, designed to ensure the implementation of the national innovation policy, and for the Russian regions. The task of the regions is not only to create economic, legal and organizational conditions for the performance of their innovation systems, but also to use the innovative competitiveness and their social and economic advantages.

Thus, the effectiveness of state management of innovation activity becomes one of the determining factors of the region's economic development and a condition for ensuring the competitiveness of the regional economy. The variety of regional practices of state support for innovation makes comparative analysis relevant.

\section{MAterials AND Methods (MODEL)}

In this paper we use the concept of the "triple helix" of building a national innovation system as the methodological basis for a comparative analysis of the effectiveness of regional mechanisms for state support of innovation activity.

The basis of this model of innovation development includes:

- strengthening the role of universities in interaction with industry and government;

- the desire to cooperate with universities, business and government with equal rights in initiating innovative processes, excluding the domination of the state;

- the fulfillment by each of the three mentioned institutions of non-traditional functions, which is the most important source of innovation [1].

To characterize the implemented programs of state support for innovations in the context of the subjects of the Southern Federal District (SFD), this paper uses a comparison of the statistical indicators characterizing innovation activity in the dynamics of recent years. As initial data characterizing innovative activity in the subjects of the Southern Federal 
District, the Rosstat data (the results of federal statistical observation in the form "Information on the innovation activity of the organization" [2]), the results of statistical surveys of innovation processes in the economy, given in the statistical compilation prepared by the Higher School of Economics in conjunction with the Federal Service of State statistics and the Ministry of Economic Development of the Russian Federation [3; 4].

The programs (subprograms) of state support for innovation activities implemented in the regions of the Southern Federal District were characterized on the basis of an analysis of budget financing of key activities aimed at supporting innovation. As the objects for comparison, the Krasnodar Territory (the subprogram "State support of small and medium business and stimulation of innovation activity in the Krasnodar Territory"), the Astrakhan (sub-program "Assistance to the development of innovative entrepreneurship"), the Volgograd (subprogram "Development of innovative activity" ), Rostov (subprogram "Innovative development of the Rostov region") of the region. The choice of these subjects as objects for comparison is due to the fact that they are all attributed by the Association of Innovative Regions of Russia to one group of innovators. From the analysis, the republics of Adygea, Kalmykia, and Crimea are excluded (belong to the group of moderately weak innovators), as well as the city of federal significance Sevastopol, included in the SFD in 2016.

When assessing the potential of innovative infrastructure of the leading universities of the Southern Federal District, the monitoring data on the effectiveness of educational institutions of higher education for 2016, conducted by the Ministry of Education and Science of the Russian Federation, were used. A comparative analysis of the infrastructure was carried out on the basis of federal state classical, technical, agrarian, medical universities of the Krasnodar Territory, Astrakhan, Volgograd and Rostov Regions that are comparable in place in regional education systems.

\section{RESULTS AND DISCUSSION}

According to the monitoring of the rating of innovation regions of Russia conducted by the Association of Innovative Regions of Russia in conjunction with the Ministry of Economic Development of the Russian Federation, the Volgograd Region, as well as a number of other subjects of the Southern Federal District (Krasnodar Region, Astrakhan, Rostov Region) is among the average innovators group, taking in 201753 place [5].

At the same time a few years ago, the cumulative index of innovative activity of organizations in the region by specialists of the Higher School of Economics was assessed very highly, yielding only to the Republic of Adygea among the subjects of the Southern Federal District. In terms of the same proportion of organizations that carried out technological innovation, the region generally belonged to the number of leaders [3]. However, in general, the economy of the District was characterized by a low level of innovative activity, and subjects of the Russian Federation that are part of the SFD were considered mainly as recipients of innovation [6].
According to the Federal State Statistics Service, in 2016, for almost all the regions under consideration, the SFD was characterized by a decrease in the share of economic entities that carry out technological, organizational, and marketing innovations. In the total number of organizations surveyed, compared to the previous period, the share of subjects of innovation in the Astrakhan region decreased by 3\%, Rostov Region by $1.5 \%$, Volgograd Region by $1.2 \%$. The boundaries of this decline exceed the average Russian level, which fixes a reduction in the share of innovation entities in the whole of the Russian Federation at $0.9 \%$. Growth in this indicator among the subjects of the Southern Federal District was demonstrated only by the Krasnodar Territory - plus $2.6 \%$ by 2015 [2].

A similar picture is observed in the field of technological innovations, which in fact represent the end result of innovation activity in the form of new or improved products and services introduced on the market. The share of business entities that carry out such innovations in the SFD in 2016 decreased in the range from $3.4 \%$ (Rostov region) to $1.4 \%$ (Krasnodar Territory). In the Volgograd region, the share of economic entities that carry out technological innovation has declined from $7.3 \%$ to $4.9 \%$ since 2013 [7].

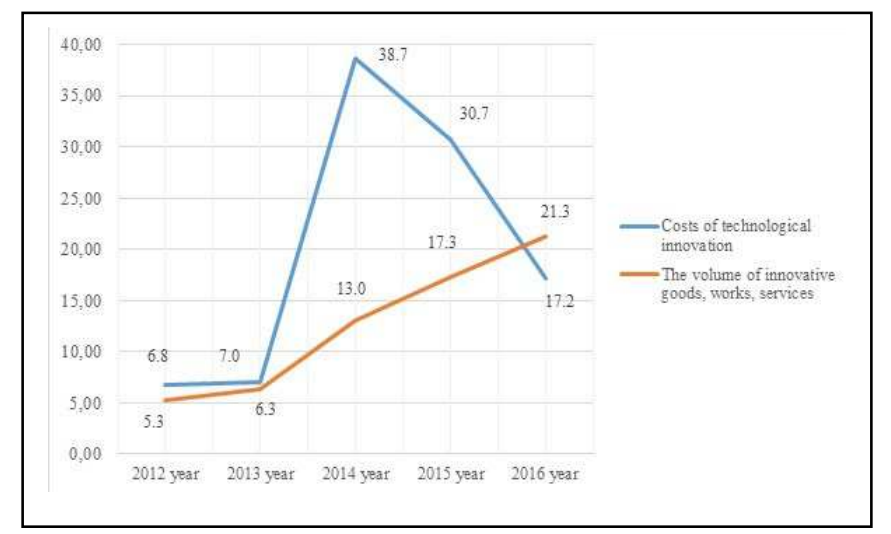

Fig. 1. Dynamics of the ratio of costs for technological innovation and the volume of innovative goods of works, services (billion rubles) in the Volgograd region (2012-2016) (compiled by the authors on the basis of Rosstat data).

Characterizing in general the dynamics of innovative activity of economic entities of the Southern Federal District for 2013-2016, it is necessary to note the deepening regional heterogeneity of innovation activity, including the loss of its competitive advantages in the field of technological innovation by the Volgograd region.

Such a backlog can not be explained only by insufficient funding. So, in the period from 2012 to 2014 (Fig. 1), the amount of costs for technological innovation (for all types of financing) increased significantly and by 2015 exceeded the volume of manufactured innovative products.

In 2016, in terms of total costs for technological innovation (including extractive, processing industries, production and distribution of electricity, gas and water, communications, activities related to the use of computers and information technology, research and development, provision 
of other services) region $\mathrm{He}$ held the second place in the Southern Federal District and was one of the leaders of the district. The cost of technological innovation in the Volgograd region amounted to $25.9 \%$ of total costs in the SFD, second only to the Rostov region (52.2\%) [7].

A similar situation is observed in the financing by the subjects of the Southern Federal District at the expense of the budgets of state subprograms in support of innovative development: the amount of financing for the subprogram "Development of Innovation Activity" of the state program "Economic Development and Innovative Economy" in the Volgograd Region amounted to 28112,700 thousand rubles. In a larger volume, only the subprogram "Innovative Development of the Rostov Region" - 57251.5 thousand rubles was financed. At the same time, in terms of output of innovative goods, works and services, Volgograd, producing $8.6 \%$ of all innovative products in the SFD, is inferior not only to the Rostov region $(54.2 \%)$, but also to the Krasnodar Territory $(29 \%)$. In the total volume of shipped goods, works and services, the share of innovative products in the Volgograd Region is only 3\% (Krasnodar Territory - $7.7 \%$, Astrakhan Region - 5.8\%, Rostov Region - 15.5\%) [7].

Evaluate the effectiveness of government programs to support innovation activity allows analysis of the structure of expenditures of regional budgets for the implementation of key activities to support innovation. The priority direction of spending regional budget funds in the Krasnodar Territory, Rostov and Astrakhan regions is the creation and development of infrastructure to support innovation. The subprogram "State support of small and medium-sized business and stimulation of innovative activity in the Krasnodar Territory" provided for in 2016 the direction of $95.5 \%$ of the total budgetary financing of innovative activities for the development of youth creativity centers. Most of the funds (83.8\%) allocated for the implementation of the subprogram "Innovative Development of the Rostov Region" were aimed at supporting the infrastructure. In the Astrakhan region, a similar indicator of the subprogram "Promoting the development of innovative entrepreneurship" was $69 \%$.

In the Volgograd region, funding $(93.2 \%$ of the total expenditure for supporting innovation) was allocated to the implementation of state scientific grants in the field of humanities and basic research, the allocation of regional prizes in the field of science and technology and state scientific grants of the Volgograd region.

The bulk of funding in 2016-17 (more than 70\%) fell on fundamental research and research in the humanities, conducted at the expense of the regional budget on cofinancing terms jointly with the Russian Humanitarian Scientific Foundation and the Russian Foundation for Basic Research. The relevance of these studies for the region was determined on the basis of proposals of higher educational institutions, without taking into account the positions of individual executive bodies of the Volgograd region. The planned social and economic effect from their implementation was poorly correlated with the goals and objectives of the subprogram "Development of Innovation Activity" and, consequently, the conducted studies could not have a direct effect on the growth of the volumes of innovative products, goods and services.

Undoubtedly, fundamental research is an important element of the innovation process: "without the active role of science, including university, the tasks of innovative development can not be solved. It is the academic activity of universities and scientific research in the education system that should serve as the most important support of the national innovation system "[8]. However, to bring their results to the stage of a real market product, a whole complex of measures is needed to convert scientific knowledge into new products and the corresponding infrastructure for the commercialization of innovations.

In the Volgograd region, such infrastructure is poorly developed. Since 2014, the Non-Profit Partnership "Assistance to Entrepreneurship" and the Fund for Promoting Venture Investments in Small Enterprises in the Scientific and Technical Sphere of the Volgograd Region have ceased to function, to help commercialize innovative developments and integrate science and industry. In the activities of the Volgograd regional business incubator, which provides support to small and medium-sized businesses, the support of innovative companies is carried out on general grounds.

Negatively affect the innovative development of the Volgograd region and gaps in the regulatory regulation of state support for innovation. In particular, the Strategy for Social and Economic Development of the Volgograd Region until 2025 and the Investment Strategy of the Volgograd Region for the period until 2020 repeat the provisions of the Concept of Long-Term Social and Economic Development of the Russian Federation for the period until 2020. Wherein Regional strategies do not take into account any features of innovative development of the region. While, for example, similar documents adopted in the Rostov region contain a whole series of measures to stimulate innovative activity of enterprises, support start-ups and ensure interaction between the state and business in developing priorities and financing research and development. Priority directions for the development of science, technology and technology in the Astrakhan region have been approved.

The second largest in terms of funding, a measure of state support for scientific and innovative activities in the region is the provision on a competitive basis of state scientific grants of the Volgograd region. For 2014, 2015, 2017 (in 2016 grants were not allocated due to lack of funding), 30 grants were allocated for 500,000 rubles each. At the same time, $50 \%$ of the applications are supported by four leading federal higher educational institutions of the region - Volgograd State Technical University, Volgograd State University, Volgograd State Agricultural University, Volgograd State Medical University.

One of the conditions for allocating grant support from the regional budget is their practical importance for solving the scientific, technical and socio-economic problems of the Volgograd region. An obvious obstacle to realizing the innovative potential of the development of Volgograd scientists is the previously noted underdevelopment of the regional infrastructure for the commercialization of 
innovations. However, the universities themselves are not ready for active innovation outside the educational process and organizing the transfer of innovation. Thus, a comparative analysis of the innovation infrastructure of the leading federal state-owned classical, technical, agrarian, medical universities of the four subjects of the Southern Federal District (Table 1) visually demonstrates the lagging behind of Volgograd universities in virtually all possible types of innovative entrepreneurship.

So, for the time being, in comparison with neighboring regions, the practice of creating small innovative enterprises is prevalent - Volgograd accounts for less than $20 \%$ of small enterprises created in leading universities in the regions under consideration. Practically, such effective forms of organization of cooperation between science, production, government bodies and consumers of innovative services, such as a business incubator and technology parks, are not used.

TABLE I. INNOVATIVE INFRASTRUCTURE OF REGIONAL UNIVERSITIES

\begin{tabular}{|l|c|c|c|}
\hline \multicolumn{1}{|c|}{ Region } & $\begin{array}{c}\text { Number of } \\
\text { business } \\
\text { incubators, } \\
\text { units }\end{array}$ & $\begin{array}{c}\text { Number of } \\
\text { technoparks, } \\
\text { units }\end{array}$ & $\begin{array}{c}\text { Number of } \\
\text { small } \\
\text { enterprises, } \\
\text { units }\end{array}$ \\
\hline Krasnodar Territory & 2 & 4 & 24 \\
\hline Astrakhan Region & 1 & 1 & 30 \\
\hline Volgograd Region & 1 & 1 & 23 \\
\hline Rostov Region & 4 & 3 & 46 \\
\hline
\end{tabular}
organizational support for the subsequent implementation of the results of implemented grants in the Subprogram reduces the effectiveness of this form of state support for innovation. It is no coincidence that starting from 2005 (the year when the regional law on granting scientific grants came into force), only 14 advanced production technologies were developed in the region in 2016, which is only $3.3 \%$ of the same index within the boundaries of the Southern Federal District [9].

\section{CONCLUSION}

Insufficient intensity of innovative processes at the regional level leads to the fact that the Volgograd region is gradually losing its competitive advantages against the background of other regions-subjects of the Southern Federal District. In part, this is due to the low effectiveness of the mechanisms of state support for innovation activities implemented in the region. The prevalence in the subprogram of innovation development of state support of scientific activity without the development of the corresponding innovation infrastructure makes it difficult for the Volgograd region's economy to transition systematically to an innovative development path.

\section{References}

[1] M. Kovazhenkov, A. Tekin. Budgeting the process of commercialization of innovation. Volgograd: Volgograd State Technical University. 228 p. [Kovazhenkov M., Tekin A. Byudzhetirovanie protsessa kommertsializatsii innovatsii. Volgograd: Volgogradskii gosudarstvennyi tekhnicheskii universitet, 2015. 228 s.].

[2] Information on the innovation activity of organizations. URL: http://www.gks.ru/free_doc/new_site/business/nauka/4-innov.htm (date of circulation: 02.02.2018). [Svedeniya ob innovatsionnoi deyatel'nosti organizatsii. URL: http://www.gks.ru/free_doc/new_site/business/nauka/4-innov.htm (data obrashcheniya: 02.02.2018)].

[3] Indicators of innovation-2013: a statistical compilation. Moscow: National Research University "Higher School of Economics", 2013. 472 p. [Indikatory innovatsionnoi deyatel'nosti: 2013: statisticheskii sbornik. M.: Natsional'nyi issledovatel'skii universitet «Vysshaya shkola ekonomiki», 2013. 472 s.].

[4] The rating of innovative development of the subjects of the Russian Federation. Issue 5 / G. I. Abdrakhmanova, P. D. Bakhtin, L. M. Gokhberg and others; Ed. L. M. Gokhberg; National Research University "Higher School of Economics." Moscow: NRE HSE, 2017. 260 p. [Reiting innovatsionnogo razvitiya sub"ektov Rossiiskoi Federatsii. Vypusk 5 / G. I. Abdrakhmanova, P. D. Bakhtin, L. M. Gokhberg i dr.; pod red. L. M. Gokhberga; Nats. issled. un-t «Vysshaya shkola ekonomiki». M.: NIU VShE, 2017. 260 s.].

[5] Rating of innovative regions of Russia: Version 2017. URL: http://iregions.org/images/files/airr17.pdf (date of circulation: 01.02.2018). [Reiting innovatsionnykh regionov Rossii: Versiya 2017. URL: http://iregions.org/images/files/airr17.pdf (data obrashcheniya: 01.02.2018)].

[6] The Order of the Government of the Russian Federation of 05.09.2011 № 1538-r "On the Approval of the Strategy for the Social and Economic Development of the Southern Federal District until 2020" // Collection of Legislation of the Russian Federation, 19.09.2011, № 38, art. 5400 [Rasporyazhenie Pravitel'stva RF ot 05.09.2011 № 1538-r «Ob utverzhdenii Strategii sotsial'no-ekonomicheskogo razvitiya Yuzhnogo federal'nogo okruga do 2020 goda» // Sobranie zakonodatel'stva Rossiiskoi Federatsii, 19.09.2011, № 38, st. 5400].

[7] S. Sazonov, I. Ezangina and A. Smolyanskii. Commercialization of innovations: the Volgograd region in the system of inter-regional competition // Scientific journal "Discourse". 2018. № 1 (15). P. 234242 [Sazonov S. P., Ezangina I. A., Smolyanskii A. P. Kommertsializatsiya innovatsii: Volgogradskaya oblast' v sisteme mezhregional'noi konkurentsii // Nauchnyi zhurnal «Diskurs». 2018. № 1 (15). S. 234-242].

[8] D. Grushevskij, E. Gushhina. Catalysts and barriers of the innovation process // National interests: priorities and security, 2011. №. 43. P. 811. [Grushevskij D. V., Gushhina E. G. Katalizatory i bar'ery innovacionnogo processa // Nacional'nye interesy: prioritety i bezopasnost', 2011. № 43. S. 8-11].

[9] Developed advanced technologies for the subjects of the Russian Federation URL: http://www.gks.ru/wps/wcm/connect/rosstat_main/rosstat/ru/statistics/sc ience_and_innovations/science/\# (date of circulation: 01.02.2018). [Razrabotannye peredovye tehnologii po sub\#ektam Rossijskoj Federacii. http://www.gks.ru/wps/wcm/connect/rosstat_main/rosstat/ru/statistics/sc ience_and_innovations/science/\# (data obrashhenija: 01.02.2018).]. 